\title{
PROFILE: KATE MOORE
}

Kate Moore (b. 1979) is an AustralianDutch musician and composer of new music. Having obtained a masters degree from the Royal Conservatory of The Hague she has been based in the Netherlands since 2002, and in 2013 she was awarded a $\mathrm{PhD}$ from the University of Sydney. In 2017 she was the recipient of the Matthijs Vermeulen Prize, the most prestigious Dutch prize for composers, for her work The Dam, commissioned for the Canberra International Festival. Her major work Sacred Environment was premiered by

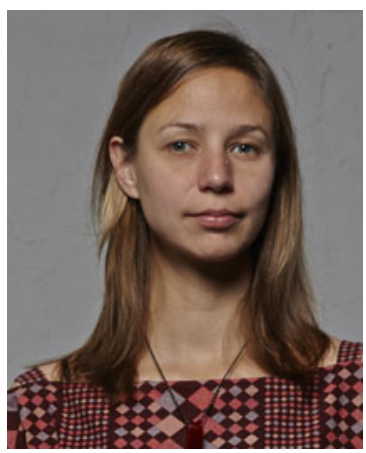

Kate Moore, photo: Johan Nieuwenhuize the Netherlands Radio Philharmonic Orchestra and Choir, with soloists Alex Oomens and Lies Beijerinck, at the Holland Festival Proms in the Concertgebouw. Her works have been released on major labels including Grammy and Eddison nominated album Dances and Canons, released on ECM New Series and Cantaloupe release Stories for Ocean Shells. Active on the international scene, Moore has had works performed by acclaimed ensembles including ASKO|Schönberg, Alarm Will Sound, The Bang On A Can All-Stars and Icebreaker. Her works have been performed in venues including The Concertgebouw, Carnegie Hall and The Sydney Opera House and at major festivals including The Holland Festival, ISCM World Music Days and MATA.

Can you remember why you wanted to become a musician?

When I was a very young person music accompanied my imaginary world and I obsessively listened to the tapes I found in my parents' collection. I listened until the magnetic strips became entangled. I was born into a sound world in which prog-rock was at its height in the late seventies and early eighties. I listened keenly to Top of the Pops. My early years were enlivened by The Beatles, Pink Floyd, Tangerine Dream and Tubular Bells among others from the family tape collection. I was drawn to the weird characters of Yellow Submarine before knowing anything about the Beatles.

My parents are amateur musicians and I listened to my mother practising Mozart sonatas on the piano and my father playing the guitar. There were recordings of Bach and a lot of Spanish guitar music, Beethoven's Fifth Piano Concerto and his symphonies. The Elgar Cello Concerto and Enigma Variations were introduced to our vinyl collection and soon to follow were recordings of Flemish School composers such as Johannes Ockeghem and Josquin des Prez. The first CD in our house came free with our CD player and was the soundtrack to Bladerunner. True to my habit, I listened to this CD obsessively until it became scratched. I listened to audio books that were accompanied by major orchestral masterworks including music by Wagner, Rimsky-Korsakov and Shostakovich. Journey to the Centre of The Earth 
by Jules Verne will forever be accompanied by Die Meistersinger von Nurnberg in my mind as the story told on tape has been tattooed into my memory.

I loved sound tracks and television from the very early eighties and television had great music. I was fixated upon Robin Hood with music by Clannad and the archaeological series Troy with the presenter Michael Wood revealed the most intriguing artefacts accompanied by bass drones that made the objects take on a new level of grandiosity and significance. Music was tied to adventure, mystery, fantasy, other worlds and infinity. My ambition at that early age was to be either and astronomer or an archaeologist, but it was actually the music associated with the earth and the sky that was my true passion. I discovered that I could be both an astronomer and an archaeologist if I became a musician.

There was a piano in the house and the notes of the piano became characters in my childhood games. The piano was my escape. I dived deeply into my own world through improvisation. The rich colourful depths of tones and resonance took me to a place beyond the limitations of my physical being, the sensation was like flying in a rainbow. I wanted to be part of that place where sound goes.

I became a musician when I began studying the cello. I began playing chamber music and orchestral repertoire. The cello was the vehicle through which I was introduced to orchestration, learning the colours of the orchestra and how they blend and interact. I encountered Stravinsky, Mussorgsky, Shostakovich, Resphigi, Tchaikovsky among others, as a cellist in youth orchestras. I was taken by the way in which sound lives, breathes and moves, with density, weight, texture and intensity, a giant organism that pulls you like the tide.

Increasingly, it seems that your work reaches beyond the familiar concert format. Why?

Curiosity for sound in all environments sets me on the path to ask questions about the nature of material and resonance. I am curious about what things sound like. I love the sound of spaces indiscriminately, moving through space and listening to how sounds change, a giant universal interactive sound installation. I am convinced that hearing was the most important sense before the modern world took hold. So much information can be ascertained about a place by simply listening to it. That which is invisible is not necessarily silent.

I love the sense of sonic perspective, hearing near and far and the way in which frequencies reflect from surfaces creating sonic shape and shadow. I do not consciously think about a space with regards to familiarity or not. Every space, whether a concert hall or a loft apartment, presents its own acoustic challenge, one of which I find joy in puzzling over and searching for a solution. I tune a piece to the space, considering the dimension and materiality of its essence. My aim is to create music that colours space, making it come to life through sound. In most instances I am not the one to choose the location of a setting as more often than not I create work upon commission where the performance and venue are already determined. My challenge is to take the specifics given to me and design a work to fit an environment. My favourite acoustic pleasure is listening to birds, frogs and cicadas and other sounds in the natural biosphere. If a place is bursting with a lot of creature song it is likely to be a good place. I have noticed that if creatures are under stress they stop singing, which is a sign of trauma within the environment. 
When you create new works do you think about an audience?

I have trouble seeing the audience as a collective entity: rather they are many individuals from different backgrounds coming together in one space. When working on a piece I am telling a story that draws a line of continuity, forging a pathway from one composition to the next. Each composition is the next chapter in a lifelong sonic adventure that makes sense in context with all the pieces past, present and future. Music must have the power to speak to an audience and be understood. The power that music possesses to reach out to an audience is an elemental component of this art form. Yet designing a piece to target a certain type of audience member and change one's musical language in order to do so weakens the vitality of the work and becomes less about the true meaning of the work and more about seeking fame, popularity or money making. In the limited number of years I have worked professionally as a composer the works that go the furthest are the ones that take risks and are raw and honest.

The relationship between composing and performing has been a preoccupation of western art music since the invention of notation. What's your current view on this?

I find the chasm between composers and performers hard to resolve. I lament that in many instances composers are kept out of the act of performing and performers feel limited to their role as interpreter rather than creator. I am torn because the interaction with performers is where the music comes to life, rehearsing the music together and feeling the energy and nerves of a performance is vital. Yet more than anything, I love removing myself from time and space in order to disappear into my secret cave of creativity and going deep into that process. It is a sacred act, one of which is private and personal. In this way I can go far developing a new piece and then emerge to share it with performers who can realise it in such a way that I could only dream of, where their ability to create a perfect phrase can cut a person in two. This is a highly skilled gift and the symbiotic relationship between creator and interpreter is valuable and exhilarating.

In my day to day routine, I play the piano or cello for hours without anyone listening, going on a journey into a new sound world, discovering the instruments and resonance for myself with no one to say whether it is right or wrong. It is liberating and always an adventure, yet I miss the social interaction with performers where the music is realised on a large scale. Increasingly I hold the view that a composer should be part of a performance of their own piece in one form or another, whether as another performer, or conductor or in the sound booth. I think it is very important for a composer to take an active role in the performance of their work and, where possible, should face the audience. 